\title{
Diagnosis of bovine tuberculosis: review of main techniques
}

\author{
D. F. Ramos ${ }^{a}$, P. E. A. Silva ${ }^{b}$ and O. A. Dellagostin ${ }^{a}$. \\ ${ }^{a}$ Núcleo de Biotecnologia, Centro de Desenvolvimento Tecnológico - CDTec, Universidade Federal de Pelotas - UFPEL, \\ CP 354, CEP 96010-900, Pelotas, RS, Brazil \\ 'Laboratório de Micobactérias, Faculdade de Medicina, Universidade Federal de Rio Grande - FURG, \\ Rua General Osório, s/n, CEP 96200-190, Rio Grande, RS, Brazil \\ *e-mail: odirad@terra.com.br
}

Received: December 10, 2013 - Accepted: July 7, 2014 - Distributed: November 30, 2015

\begin{abstract}
Bovine tuberculosis (BTB) remains an important economic and zoonotic problem in Latin America. Traditionally, the fight against BTB is initiated by the implementation of routine diagnostic tests for certification of free properties. The diagnosis of BTB can be made by direct and indirect methods, in which we can mention clinical, post mortem, histopathological, immunological, bacteriological and molecular methods. The renewal of scientific interest in tuberculosis in recent year has led to develop and improve methods of diagnosis, prevention, control and eradication of BTB. The aim of this review is to present and discuss different diagnosis methods of BTB.
\end{abstract}

Keywords: tuberculosis bovine, diagnosis, Mycobacterium bovis, new techniques.

\section{Diagnóstico de tuberculose bovina: revisão das principais técnicas}

\begin{abstract}
Resumo
A tuberculose bovina (BTB) continua sendo um importante problema econômico na América Latina, com potenciais consequências zoonóticas. Tradicionalmente, a luta contra a tuberculose bovina tem sido iniciada pela execução de testes de diagnóstico de rotina para a certificação de propriedades livres da doença. O diagnóstico de BTB pode ser feito através de métodos diretos e indiretos, nos quais podemos citar os métodos clínicos, post mortem, histopatológicos, imunológicos, bacteriológicos e moleculares. A renovação do interesse científico em tuberculose nos últimos anos tem levado à necessidade de desenvolver e melhorar os métodos de diagnóstico, prevenção, controle e erradicação da BTB. O objetivo deste artigo é analisar e discutir sobre os diferentes métodos de diagnóstico de BTB.
\end{abstract}

Palavras-chave: tuberculose bovina, diagnóstico, Mycobacterium bovis, novas técnicas.

\section{Introduction}

Bovine tuberculosis (BTB) is a chronic bacterial disease caused by Mycobacterium bovis, which can also infect and cause tuberculosis (TB) in badgers, deer goats, pigs, camelids (llamas and alpacas), dogs and cats, as well as man and other mammals (OIE, 2009). This disease is still common in developing countries and severe economic losses can occur from livestock deaths, chronic disease and trade restrictions. In some situations, BTB may also be a serious threat to endangered species. Consequently, about $70 \%$ of the cattle bred in Latin America are held in areas with high disease prevalence and nearly $17 \%$ in areas virtually free from BTB (de Kantor and Ritacco, 2006).

The disease is a major cause of economic losses, both in relation to individual herds, and for the economy of the countries where it still occurs. Brazil launched a nationwide program of BTB control in 2001, and added further regulations in 2004 (Brasil, 2006). According to a tuberculin testing survey conducted in 1998, an average of $7.1 \%$ of herds was infected, ranging from $2.8 \%$ in the
Central West to $58.3 \%$ in the Northern regions. M. bovis has been isolated from livestock pathological specimens (bovine, buffalo and swine), and from raw milk, confirming the risk for humans ingesting raw or un-pasteurized milk, as well as under-cooked animal products (Leite et al., 2003).

As the cattle industry is one of the highlights of Brazilian agribusiness, with the second largest herd in the world, with about 205 million head of cattle (IBGE, 2009). Official rate is $1.3 \%$ of the national herd infected with $M$. bovis, which represent a large number in the order of 2.5 million animals. Recent research confirmed that the infection is more concentrated in dairy cattle, where infection rates can reach $15 \%$ of herds with at least one infected animal (Brasil, 2006).

The infection leads to a decrease from 10 to $20 \%$ of milk production, loss of weight and a reduction of fertility. In addition, there is condemnation of carcasses of infected animals, and restrictions to export meat to countries where BTB is controlled (Brasil, 2006; Collins, 2006). 
It is believed to occur under-reporting of reactive cases that, combined with fewer tests than necessary, contribute to the inaccuracy of official data (Brasil, 2006). In recent years, more diagnostic methods have helped more effective programs of prevention, control and eradication of disease (Collins, 2006). Several methods have been to this end both the direct detection of the etiologic agent in biological material, as in the indirect detection through the identification of a host immune response to the etiologic agent. (de la Rua-Domenech et al., 2006). Among which we can mention the tuberculin test, culture, post mortem examination, ELISA, interferon-gama and molecular assays (Schiller et al., 2010). Even so, it is necessary to validate these tests, taking into account the differences between clinical samples and evaluated countries in which they are employed.

\section{Clinical Diagnosis}

Tuberculosis (TB) is usually a chronic debilitating disease in cattle, but it can occasionally be acute and rapidly progressive. In countries with eradication programs, most infected cattle are identified early and symptomatic infections are uncommon. In the late stages, common symptoms include progressive emaciation, a low-grade fluctuating fever, weakness and inappetence. Animals with pulmonary involvement usually have a moist cough that is worse in the morning, during cold weather or exercise, and may have dyspnea or tachypnea (Une and Mori, 2007).

In some animals, the retropharyngeal or other lymph nodes enlarge and may rupture and drain. Greatly enlarged lymph nodes can also obstruct blood vessels, airways, or the digestive tract. If the digestive tract is involved, intermittent diarrhea and constipation may be seen (Une and Mori, 2007).

The symptoms of bovine tuberculosis usually take months to develop in cattle. Infections can also remain dormant for years and reactivate during periods of stress or in old age. Therefore, the BTB can be difficult to diagnose based only on the clinical signs, especially in developed countries, where the number of severe cases of animals with clinical evidence may be limited or absent and most are diagnosed by routine testing or found at the slaughterhouse (Cousins, 2001).

\section{Post Mortem Diagnosis}

The pathologic diagnosis, or post mortem, the BTB, while performing autopsies or sanitary inspection of carcasses in slaughterhouses refrigerated presents considerable difficulty, since many pathogens such as Actynomices bovis, Trueperella pyogenas and others, have a granulomatous inflammation and morphologic characteristics similar to BTB. The conventional post mortem examination has detected approximately $47 \%$ of presumptive BTB lesions in carcasses of cattle slaughtered. Despite this, the anatomo-pathology analyses has been crucial for the diagnosis of BTB in the control programs (Biet et al., 2005).
In recent years, in developed countries, the inspection of carcasses for evidence of BTB has come increasingly to be regarded as an extension of the national animal health program rather than solely as a control point in the prevention of human cases of tuberculosis caused by $M$. bovis, as was so often the case a century or more ago. Now, however, it is important to focus also on the contribution which efficient meat inspection, coupled with real-time data retrieval, and supported by advanced diagnostic bacteriology including DNA-based strain typing, that can provide the epidemiological data for to the eradication and control of this zoonotic disease (Berends et al., 1993; Schiller et al., 2010). This disease is characterized by the formation of granulomas where bacteria are located. These granulomas are usually yellowish and either caseous, caseo-calcareous or calcified, and often encapsulated. Some tubercles are small enough to be missed by the naked eye, unless the tissue is sectioned. In cattle, tubercles are found in the lymph nodes, particularly those of the head and thorax. They are also common in the lung, spleen, liver and the surfaces of body cavities (de Kantor and Ritacco, 2006).

As evidenced by findings at post mortem examination, the tuberculosis in cattle is primarily a respiratory disease. The origin of the infected droplet or aerosol exhaled by the tuberculous animal, bovine or otherwise, and its role in the dissemination of $M$. bovis among animals and in the environment is all too often overlooked in the investigation of breakdowns, even considering that, the pattern and extent of exposure of the rest of the herd to tuberculous cattle identified, should be the basis for the assessment of the severity of the breakdown and of the current status. Again, that the fundamentals of the control of an infectious disease require to be kept in mind at all stages of the investigation and management of the outbreak; otherwise, wrong conclusions and decisions may result, with untoward consequences both for the herdowner and the programme (Collins, 2006). The digestive tract is also a route of infection for bovine tuberculosis, especially in calves fed milk from cows with tuberculous mastitis or through ingestion of contaminated water or forage. In this case, the primary complex is located in the digestive organs and lymph nodes (Good and Duignan, 2011).

An adequate system of disease control and epidemiological surveillance relies on slaughterhouse inspection. This implies a sound infrastructure, highly trained staff and a reliable register system for tracing back to the herd of origin. Official inspection is currently in vigor in 22 countries. Nevertheless, the scarcity of qualified veterinary inspectors and trained personnel limits the efficiency of post mortem examination in several countries (de Kantor and Ritacco, 2006). Therefore, the monitoring in the abattoir has been important to lesion detection during commercial slaughter that is used as cost-efficient method for passive surveillance of BTB. The success of such investigations is highly variable, since, the lesion detection exhibits a major lack in sensitivity. 


\subsection{Histopathological diagnosis}

A presumptive diagnosis can also be made by histopathology and/or the microscopic demonstration of acid-fast bacilli, as a complementary form of post mortem lesions diagnostic presumptive BTB. More direct methods for tuberculosis diagnosis are based on the isolation or detection of the bacterium in sputum samples or biopsies (mostly in humans) or at post mortem, from tuberculous organ lesions (generally in animals). The presence of mycobacteria in a given sample can be assessed by Ziehl-Neelsen staining followed by light microscopy or auramine $\mathrm{O}$ staining and fluorescence microscopy (Marais et al., 2008). These techniques are based on the tinctorial properties common in mycobacteria and microorganisms of the genus Nocardia, Rhodococcus and Corynebacterium, known as acid resistant bacilli. That is named because they can retain the fuchsine-heated material after treatment for alcohol-acid. In this type of coloring, alcohol acid resistant microorganisms can be observed under the microscope (Marais et al., 2008).

The presumptive diagnosis of mycobacteriosis can be made if the tissue has characteristic histological lesions such as caseous necrosis, mineralisation, epithelioid cells, multinucleated giant cells and macrophages. As lesions are often paucibacillary, the presence of acid-fast organisms in histological sections may not be detected, although M. bovis can be isolated in culture. However, large numbers of acid-fast organisms are seen in lesions in primates, felids, mustelids (badgers) and marsupials (brush-tailed possums) (Corner et al., 2011; Schiller et al., 2010).

Recent work with $M$. tuberculosis suggests that the auramine $\mathrm{O}$ staining technique may be more sensitive and specific than Ziehl-Neelsen staining (Marais et al., 2008). However, microscopic detection of mycobacteria shows a generally low sensitivity (from 50 to $70 \%$ ) for human sputum samples. In addition, many features, including the dyeing property, overlap in the genus Mycobacterium and Nocardia making it difficult in some cases, the differentiation between both. This is mainly due to the requirement of a high bacterial load for microscopy. A much higher sensitivity can be achieved by prior culture of the bacteria. Culture is still regarded as the gold standard for TB diagnosis despite certain limitations, like the difficulty of obtaining representative samples from live animals, the need for pretreatment, slow growth, and additional time for identification by additional methods (Medeiros et al., 2010).

\subsection{Immunological diagnosis}

The immunological diagnosis of BTB is based on delayed-type hypersensitivity (DTH) reaction in vivo, represented by the tuberculin skin test (TST) (Schiller et al., 2010). This evidence is an indirect method of diagnosis of TB and can reveal incipient infections, with three to eight weeks after contact with the M. bovis, since techniques are employed using standard reagents and equipment. It is a test widely used since it was recommended by Robert Koch in 1890 (Monaghan et al., 1994).
The tuberculin by Koch's discovery, after some modifications, is currently called purified protein derivative (PPD), widely used for the indirect diagnosis of BTB in vivo. In the beginning the test was performed with PPD obtained from a M. tuberculosis strain, however, since the sixties the test in bovine is carried out with PPD obtained from the M. bovis AN5 strain. Advantages for the use of PPD and reasons for its wide use is low costs, high availability, long history of use and, for a long time, the lack of alternative methods to detect BTB. Still, this test has many known limitations including difficulties in administration and interpretation of results, need for a second-step visit, low degree of standardization, and imperfect test accuracy (de la Rua-Domenech et al., 2006; Schiller et al., 2010).

Borsuk et al. (2009) identified different proteins in bovine and avium PPD from the distinct countries, with the several efficiency levels, because the strains used to prepare the bovine and avium PPD are the same, but the media used to grow the bacteria, the inactivation procedure and precipitation method are different. On the other hand, the cross-reactions assigned, usually in the presence of PPD antigens common to different species of mycobacteria, is the most important cause of sensitization since it does not distinguish between infection with M. tuberculosis/bovis and BCG vaccination, or exposure to environmental mycobacteria (Young et al., 2009). However, this test is the only validated and used routinely and widely for more than 85 years (Huebner et al., 1993).

Thus, the test specificity is not only influenced by the purity, potency, and dosage of the PPD and strictness of interpretation of the response in the animal, but it is also influenced by sensitization of the animal by environmental mycobacteria. In addition, it has been recently showed that the genetic background of the animal can also influence the reaction to tuberculin (Amos et al., 2013). The standard TST is estimated to be able to detect around $40-80 \%$ of infected animals (Francis et al., 1978 apud Monaghan et al., 1994; Karolemeas et al., 2012). Clearly, there is an urgent need form significant improvement on the test, so that it could be used with more confidence for enforcing the "test-andslaughter' policy, reducing the number of false positive, as well as false negative results. This would certainly improve the effectiveness of the control program, and reduce the financial burden on cattle industry.

The predominant immunological response in M. bovis-infected cattle is affected by T lymphocytes (de la Rua-Domenech et al., 2006). Ante mortem tests of cellular immunity are very important for the control of BTB since they can identify $M$. bovis-infected animals very early. The tuberculin skin test and the interferon-gamma test are both based on the detection of the early cell-mediated immune response in tuberculosis infection. However, at late disease stages, the cell-mediated immune response can wane as opposed to a generally increasing humoral immune response and these tests can therefore give false negative results (de la Rua-Domenech et al., 2006). This is of importance for the diagnosis of BTB in settings where no 
or poor disease control measures are applied and where the percentage of late stage diseased animals is believed to be high. Therefore, in developing countries, serological tests, which are based on the detection of the humoral immune response, may be of particular use. This serological test are being incorporated into BTB eradication programs in many countries (de la Rua-Domenech et al., 2006; Schiller et al., 2010; Vordermeier et al., 2008), either in a serial testing regime as confirmatory test after the caudal fold test to enhance specificity or in a parallel testing regime to enhance sensitivity of DTHs. Some of the problems related to the development of serological tests for tuberculosis diagnosis include the observed highly variable antibody responses between individuals to mycobacterial antigens and antigenic variation between mycobacterial strains.

\subsubsection{Gamma interferon assays (Bovigam)}

Since 2006, the IFN $\gamma$ assay Bovigam $^{\circledR}$, Prionics, Switzerland) is an assay through which it is possible to verify the existence of cell-mediated immune response developed by the body of the animal in response to mycobacterial infection. IFN $\gamma$ produced by $\mathrm{T}$ lymphocytes of the infected animal is detected, using monoclonal anti-IFN $\gamma$. The lack of detection of IFN $\gamma$ characterizes the negativity of the animal to infection $M$. bovis since lymphocytes from uninfected cattle do not produce this cytokine in specific ways. As this is an in vitro test that has the advantage of not interfering with the immune status of the animal and may be repeated in the same animal is the need to respect the period of desensitization. This assay showed the increase in the sensitivity and the possibility of more rapid repeat testing, no need for a second visit to the farm and more objective test procedures and interpretation in comparison to the TST (Faye et al., 2011; Neill et al., 1994; Schiller et al., 2010; Wood and Jones, 2001).

The strategic application of the IFN $\gamma$ assay, as an adjunct to the tuberculin test, can facilitate the early removal of infected animals in problem herds that are otherwise negative to the tuberculin test. Recognition that the objective of the assay is to identify high-risk animals that are potentially infectious for other cattle can generate confidence in herd-owners that rational decisions can be made based on sound scientific principles, and that effective schemes can be devised to make more rapid progress in the elimination of the infection from affected herds (Gormley et al., 2006).

The assay is based on the release of IFN $\gamma$ from sensitized lymphocytes during a 16-24 hours incubation period with specific antigen and makes use of comparison of IFN $\gamma$ production following stimulation with avium and bovine PPD (Alito et al., 2003). Besides high logistical demands (culture start is required within $24 \mathrm{~h}$ after blood sampling), and its high costs, showed the same difficulties in the standardization already discussed in relation to the TST with the tuberculin (de la Rua-Domenech et al., 2006; Schiller et al., 2010; Vordermeier et al., 2008). ESAT6 and CFP10, M. tuberculosis complex specific antigens, have also been used to improve IFN $\gamma$ assay specificity, especially in population groups testing positive to the TST. The use of these antigens may also offer the ability to differentiate BCG-vaccinated from unvaccinated animals. (Faye et al., 2011; Fentahun and Luke, 2012).

\subsubsection{Enzyme-linked immunosorbent assays (ELISA)}

Although serological assays cannot be considered first choice diagnostic methods, many researchers describe strategies for their use. The indirect ELISA technique measures the binding of specific antibodies to an antigen (de la Rua-Domenech et al., 2006). An advantage of the ELISA is its simplicity, but sensitivity is limited mostly because of the late and irregular development of humoral immune response in cattle during the course of the disease.

In order to diagnose cattle infected by M. bovis, antigens usually employed are the PPD and single or associated purified antigens from $M$. bovis such as antigens of the Ag85 that complex represents a major part of the secreted proteins, and MPB70 and it highly homologous protein MPB83, secreted mycobacterial proteins with limited species distribution. Most of these antigens have achieved a sensitivity and specificity of around 90\%, and their recommendations are based on the existence of anergic animals, as well as increased antibody titres in more advanced stages of the disease (Faye et al., 2011; McNair et al., 2001; Welsh et al., 2005).

Recently, the development of a lateral flow test that is based on the detection of more than one antigen has shown promising results for tuberculosis diagnosis in certain animal species (e.g. in elephant), although it may not be suitable for others, such as buffaloes (Greenwald et al., 2009; Michel and Simoes, 2009). Another recently developed serological test for animals is based on antibody detection using fluorescence polarization but has shown variable effectiveness in different settings (Jolley et al., 2007; Ngandolo et al., 2009).

\subsection{Bacterial isolation}

Isolation of $M$. bovis is considered "gold standard" for BTB diagnosis. However, the long period required for the isolation and biochemical identification, is one of its critical points, and may require more than twelve weeks to complete the final diagnosis, and also low sensitivity (Collins et al., 1994). The samples collected are submitted to decontamination methods, involves the addition of $\mathrm{NaOH}, \mathrm{H}_{2} \mathrm{SO}_{4}$, oxalic acid, or quaternary ammonium compounds, to eliminate such competitive microorganisms, and, unfortunately, the toxic effects may affect mycobacterial viability, thereby interfering with culturing the organism (Ambrosio et al., 2008; Medeiros et al., 2010; Young et al., 2005).

The major limitation for systematic cultivation of M. bovis of animals is to obtain samples, and is usually held in autopsies and slaughterhouses. To overcome this limitation, studies have suggested the use of nasal swabs as an alternative to reduce contamination of samples and increase the sensitivity of the method (Ambrosio et al., 2008). As a limiting factor in isolation is often the poor quality 
of the samples submitted, and all efforts should be made to ensure that the laboratory receives samples of good quality to enable the correct diagnosis of BTB.

Despite these issues, uses the MGIT system is still favored over the use of solid media due to decreased time to recovery and higher sensitivity (Robbe-Austerman et al., 2013). Even so, it has been reported that upon detection of tuberculin-positive animals, tuberculous lung lesions were evident in $70 \%$ of reactive cattle; the $M$. bovis was isolated from nasal or tracheal swabs only in $19 \%$ of confirmed cases (McIlroy et al., 1986; Schiller et al., 2010). Therefore, the combination of data from the bacterial culture and pathology can be useful for more accurate diagnosis of BTB (Barry Third et al., 2009; Young et al., 2009).

The culture presents higher sensitivity; furthermore, it offers the advantage of species identification. Continuous education and training of slaughter inspectors are certainly of major importance. In addition, the combined use of liquid and solid culture media has been reported to improve culture sensitivity (Hines et al., 2006). Therefore, improving the conventional microbiological method for rapid diagnosis represents a major advantage in the fight against tuberculosis in humans and cattle and has considerable impact on disease control in cattle (Corner, 1994).

Characteristic growth patterns and colonial morphology can provide a presumptive diagnosis of $M$. bovis; however, every isolate needs to be confirmed. It is necessary to distinguish $M$. bovis from the other members of the M. tuberculosis complex (Richter et al., 2004), i.e. M. tuberculosis (the primary cause of tuberculosis in humans), M. africanum (occupies an intermediate phenotypic position between M. tuberculosis and M. bovis), M. microti (the 'vole bacillus', a rarely encountered organism), M. pinnipedii and M. caprae (Meikle et al., 2007). This underscores the need for more sensitive, accurate, and faster methods to assist in the control of this zoonosis such as molecular methods.

\subsection{Molecular diagnosis}

Performing the differentiation between the organisms that cause human and bovine tuberculosis is not a simple task. Among the main problems in the distinguishing of mycobacteria to the species as causal, this diversity of techniques and tests that are needed, beyond the time necessary for complete identification (Telenti et al., 1993). A series of classical tests based on growth, phenotypic and biochemical properties have been traditionally used to separate the members of the M. tuberculosis Complex (de la Rua-Domenech et al., 2006). However, together, these tests can be slow, cumbersome, inaccurate, not reproducible and time-consuming, can give an ambiguous result and cannot be performed in any laboratory. Nevertheless, polymerase chain reaction (PCR) has been successfully applied to detect members of the M. tuberculosis complex and is especially useful for the direct detection of $M$. bovis in bovine tissue samples (Zumarraga et al., 2005).

The addition of assays such as PCR for detection of $M$. bovis DNA from formalin-fixed specimens has further enhanced some surveillance. PCR assays to detect
MTB bacteria are currently less sensitive than culture techniques. Therefore, important further steps would be to improve PCR sensitivity and to standardize PCR methods (Schiller et al., 2010).

One of the key advances in our understanding of M. bovis has been the elucidation of the complete genome sequence of the pathogen (Garnier et al., 2003). The availability of the genome sequence of M. tuberculosis allows (Cole et al., 1998) us to perform comparative analyses that are providing insight into some of the key differences between the human and bovine bacillus. M. bovis is a close relative of $M$. tuberculosis, and they share genetic identity over $99 \%$ at the whole genome level and identical $16 \mathrm{~S}$ rRNA sequences (de la Rua-Domenech et al., 2006). Some studies have supported the fact that although slight differences are found in the genome sequence of $M$. tuberculosis and $M$. bovis and reflected in the physiology and host range spectrum (Alvarez et al., 2009).

Distinct in-house PCR methods have been proposed for the rapid detection of small amount of $M$. bovis DNA. These methods were mainly used to confirm the etiology of macroscopic lesions detected at slaughterhouse inspection and to detect $M$. bovis in milk specimens (de Kantor and Ritacco, 2006). Regarding the use of PCR for diagnosis of BTB, this approach has been extensively evaluated in detecting mycobacteria in milk, fresh tissues, and tissues fixed in formalin and embedded in paraffin. Several primers have been used to amplify the sequence of $16 \mathrm{~S}-23 \mathrm{~S} \mathrm{rRNA}$, the insertion sequences $I S 6110$ and ISI08, as well as genes coding for proteins such as MPB70 of $24 \mathrm{kDa}, 38 \mathrm{kDa}$ antigen $\mathrm{B}$ and HSP of $65 \mathrm{kDa}$ (Collins, 2006; Cosivi et al., 1998; Dvorská et al., 2001; Telenti et al., 1993).

An approach that has been used is based on the amplification of a DNA sequence called RD7, present in M. tuberculosis and absent in M. bovis. However, this deletion is also present in M. microti and in some $M$. africanum and $M$. pinnipedii, which makes the test not very specific (Cole et al., 1998; Etchechoury et al., 2010). The most limiting steps while using this technique are the extractions of genomic DNA of amplifiable quality and availability of oligonucleotides with high specificity for different species, and cross-contamination, which has been the problem in the standardization of molecular methods. The variation in the results of authors regarding the specificity and sensitivity of these tests are due to many factors such as the type of sample used, the use of several methodologies in sample preparation, amplification system and detection of the product amplified and this will only be settled by reliable protocols and standardized by several laboratories (OIE, 2009).

Therefore, although direct PCR can produce a rapid result, it is recommended that culture be used in parallel to confirm a viable M. bovis (Warren et al., 2006). Nevertheless, it has already been observed with culture and PCR of M. bovis in bovine milk (Zumarraga et al., 2005), PCR that is more sensitive than culture, a fact that may be attributable to the decontamination method before culture that may kill a high proportion of bacteria (Meikle et al., 2007). 
Currently, there is only one commercially available diagnostics kit for the differentiation of the MTB, this assay distinct members of the MTB using highly conserved single nucleotide polymorphisms (SNP) in the gyrB gene (Richter et al., 2004). However, it is limited as it does not distinguish M. canettii and M. pinnipedii. While SNP's have commonly been used for accurate discriminate of members of the M. tuberculosis Complex further validation of the SNP identified in this study for the specific detection of M. caprae is required (Reddington et al., 2011).

\section{Conclusion}

Despite all the efforts to control BTB, the disease persists, with serious implications this zoonotic disease constitutes a significant economic burden to the agricultural industries and for human health. Eradication programs based on tuberculin testing and subsequent slaughter of positive animals have been successful in many developed countries. However, a tuberculin test is limited in its specificity and sensitivity, so culture should be used to confirm the presence of M. bovis. Molecular technics like PCR can also detect $M$. bovis directly in clinical samples. Moreover, genetic fingerprinting techniques (e.g. spoligotyping) can distinguish different strains of $M$. bovis.

Many factors contribute to the persistence of BTB, such as the limitations of diagnostic tests (concerning both sensitivity and specificity), larger herd sizes, increase in animal movements and trade, and limited options for control, such as limitations on whole herd depopulation. Therefore, considering current trends associated with BTB control and eradication programs, it is important to increasingly focus resources to target control strategies based on more effective diagnostic methods.

\section{References}

ALITO, A., MCNAIR, J., GIRVIN, R.M., ZUMARRAGA, M., BIGI, F., POLLOCK, J.M. and CATALDI, A., 2003. Identification of Mycobacterium bovis antigens by analysis of bovine T-cell responses after infection with a virulent strain. Brazilian Journal of Medical and Biological Research, vol. 36, no. 11, pp. 15231531. http://dx.doi.org/10.1590/S0100-879X2003001100011. PMid:14576908.

ALVAREZ, A.H., ESTRADA-CHAVEZ, C. and FLORES-VALDEZ, M.A., 2009. Molecular findings and approaches spotlighting Mycobacterium bovis persistence in cattle. Veterinary Research, vol. 40, no. 3, pp. 22. http://dx.doi.org/10.1051/vetres/2009005. PMid:19220975.

AMBROSIO, S.R., OLIVEIRA, E.M.D, RODRIGUEZ, C.A.R., FERREIRA NETO, J.S. and AMAKU, M., 2008. Comparison of three decontamination methods for Mycobacterium bovis isolation. Brazilian Journal of Microbiology, vol. 39, no. 2, pp. 241-244. http://dx.doi.org/10.1590/S1517-83822008000200008. PMid:24031209.

AMOS, W., BROOKS-POLLOCK, E., BLACKWELL, R., DRISCOLL, E., NELSON-FLOWER, M. and CONLAN, A.J., 2013. Genetic predisposition to pass the standard SICCT test for bovine tuberculosis in British cattle. PLoS One, vol. 8, no.
3, pp. e58245. http://dx.doi.org/10.1371/journal.pone.0058245. PMid:23554880.

BARRY THIRD, C.E., BOSHOFF, H.I., DARTOIS, V., DICK, T., EHRT, S., FLYNN, J., SCHNAPPINGER, D., WILKINSON, R.J. and YOUNG, D., 2009. The spectrum of latent tuberculosis: rethinking the biology and intervention strategies. Nature Reviews. Microbiology, vol. 7, no. 12, pp. 845-855. PMid:19855401.

BERENDS, B.R., SNIJDERS, J.M.A. and VAN LOGTESTIJN, J.G., 1993. Efficacy of current EC meat inspection procedures and some proposed revisions with respect to microbiological safety: a critical review. Veterinary Research, vol. 133, no. 17, pp. 411-415. PMid:8279110.

BIET, F., BOSCHIROLI, M.L., THOREL, M.F. and GUILLOTEAU, L.A., 2005. Zoonotic aspects of Mycobacterium bovis and Mycobacterium avium-intracellulare complex (MAC). Veterinary Research, vol. 36, no. 3, pp. 411-436. http://dx.doi.org/10.1051/ vetres:2005001. PMid:15845232.

BORSUK, S., NEWCOMBE, J., MENDUM, T.A., DELLAGOSTIN, O.A. and MCFADDEN, J., 2009. Identification of proteins from tuberculin purified protein derivative (PPD) by LC-MS/ MS. Tuberculosis, vol. 89, no. 6, pp. 423-430. http://dx.doi.org/ 10.1016/j.tube.2009.07.003. PMid:19683472.

BRASIL. Ministério da Agricultura, Pecuária e Abastecimento - MAPA, 2006. Programa Nacional de Controle e Erradicação da Brucelose e Tuberculose Animal - PNCEBT. Brasília: MAPA/ SDA/DSA.

COLE, S.T., BROSCH, R., PARKHILL, J., GARNIER, T., CHURCHER, C., HARRIS, D., GORDON, S.V., EIGLMEIER, K., GAS, S., BARRY THIRD, C.E., TEKAIA, F., BADCOCK, K., BASHAM, D., BROWN, D., CHILLINGWORTH, T., CONNOR, R., DAVIES, R., DEVLIN, K., FELTWELL, T., GENTLES, S., HAMLIN, N., HOLROYD, S., HORNSBY, T., JAGELS, K., KROGH, A., MCLEAN, J., MOULE, S., MURPHY, L., OLIVER, K., OSBORNE, J., QUAIL, M.A., RAJANDREAM, M.A., ROGERS, J., RUTTER, S., SEEGER, K., SKELTON, J., SQUARES, R., SQUARES, S., SULSTON, J.E., TAYLOR, K., WHITEHEAD, S. and BARRELL, B.G., 1998. Deciphering the biology of Mycobacterium tuberculosis from the complete genome sequence. Nature, vol. 393, no. 6685, pp. 537-544. http://dx.doi. org/10.1038/31159. PMid:9634230.

COLLINS, D.M., RADFORD, A.J., DE LISLE, G.W. and BILLMAN-JACOBE, H., 1994. Diagnosis and epidemiology of bovine tuberculosis using molecular biological approaches. Veterinary Microbiology, vol. 40, no. 1-2, pp. 83-94. http://dx.doi. org/10.1016/0378-1135(94)90048-5. PMid:7915446.

COLLINS, J.D., 2006. Tuberculosis in cattle: strategic planning for the future. Veterinary Microbiology, vol. 112, no. 2-4, pp. 369-381. http://dx.doi.org/10.1016/j.vetmic.2005.11.041. PMid:16330164.

CORNER, L.A., 1994. Post mortem diagnosis of Mycobacterium bovis infection in cattle. Veterinary Microbiology, vol. 40, no. 1-2, pp. 53-63. http://dx.doi.org/10.1016/0378-1135(94)90046-9. PMid:8073629.

CORNER, L.A., MURPHY, D. and GORMLEY, E., 2011. Mycobacterium bovis infection in the Eurasian badger (Meles meles): the disease, pathogenesis, epidemiology and control. Journal of Comparative Pathology, vol. 144, no. 1, pp. 1-24. http://dx.doi.org/10.1016/j.jcpa.2010.10.003. PMid:21131004.

COSIVI, O., GRANGE, J.M., DABORN, C.J., RAVIGLIONE, M.C., FUJIKURA, T., COUSINS, D., ROBINSON, R.A., HUCHZERMEYER, H.F., DE KANTOR, I. and MESLIN, 
F.X., 1998. Zoonotic tuberculosis due to Mycobacterium bovis in developing countries. Emerging Infectious Diseases, vol. 4, no. 1, pp. 59-70. http://dx.doi.org/10.3201/eid0401.980108. PMid:9452399.

COUSINS, D.V., 2001. Mycobacterium bovis infection and control in domestic livestock. Revue Scientifique et Technique (International Office of Epizootics), vol. 20, no. 1, pp. 71-85. PMid:11288521

DE KANTOR, I.N. and RITACCO, V., 2006. An update on bovine tuberculosis programmes in Latin American and Caribbean countries. Veterinary Microbiology, vol. 112, no. 2-4, pp. 111-118. http://dx.doi.org/10.1016/j.vetmic.2005.11.033. PMid:16310980.

DE LA RUA-DOMENECH, R., GOODCHILD, A.T., VORDERMEIER, H.M., HEWINSON, R.G., CHRISTIANSEN, K.H. and CLIFTONHADLEY, R.S., 2006. Ante mortem diagnosis of tuberculosis in cattle: a review of the tuberculin tests, gamma-interferon assay and other ancillary diagnostic techniques. Research in Veterinary Science, vol. 81, no. 2, pp. 190-210. http://dx.doi.org/10.1016/j. rvsc.2005.11.005. PMid:16513150.

DVORSKÁ, L., BARTOS, M., MARTIN, G., ERLER, W. and PAVLIK, I., 2001. Strategies for differentiation, identification and typing of medically important species of mycobacteria by molecular methods. Vyzkumny Ustav Veterinarniho Lekarstvi, vol. 46 , no. 11-12, pp. 309-328.

ETCHECHOURY, I., VALENCIA, G.E., MORCILLO, N., SEQUEIRA, M.D., IMPERIALE, B., LÓPEZ, M., CAIMI, K., ZUMÁRRAGA, M.J., CATALDI, A. and ROMANO, M.I., 2010. Molecular typing of Mycobacterium bovis isolates in Argentina: first description of a person-to-person transmission case. Zoonoses and Public Health, vol. 57, no. 6, pp. 375-381. http://dx.doi. org/10.1111/j.1863-2378.2009.01233.x. PMid:19912616.

FAYE, S., MOYEN, J.L., GARES, H., BENET, J.J., GARINBASTUJI, B. and BOSCHIROLI, M.L., 2011. Determination of decisional cut-off values for the optimal diagnosis of bovine tuberculosis with a modified IFNgamma assay $\left(\right.$ Bovigam $\left.^{\circledR}\right)$ in a low prevalence area in France. Veterinary Microbiology, vol. 151, no. 1-2, pp. 60-67. http://dx.doi.org/10.1016/j.vetmic.2011.02.026. PMid:21420258.

FENTAHUN, T., and LUKE, G., 2012. Diagnostic techniques of bovine tuberculosis: a review. African Journal of Basic and Applied Sciences, vol. 4, no. 6, pp. 192-199.

GARNIER, T., EIGLMEIER, K., CAMUS, J.C., MEDINA, N., MANSOOR, H., PRYOR, M., DUTHOY, S., GRONDIN, S., LACROIX, C., MONSEMPE, C., SIMON, S., HARRIS, B., ATKIN, R., DOGGETT, J., MAYES, R., KEATING, L., WHEELER, P.R., PARKHILL, J., BARRELL, B.G., COLE, S.T., GORDON, S.V. and HEWINSON, R.G., 2003. The complete genome sequence of Mycobacterium bovis. Proceedings of the National Academy of Sciences of the United States of America, vol. 100, no. 13, pp. 7877-7882. http://dx.doi.org/10.1073/pnas.1130426100. PMid:12788972.

GOOD, M. and DUIGNAN, A., 2011. Perspectives on the history of bovine TB and the Role of tuberculin in bovine TB eradication. Veterinary Medicine International, vol. 2011, pp. 410470. http:// dx.doi.org/10.4061/2011/410470. PMid:21547209.

GORMLEY, E., DOYLE, M.B., FITZSIMONS, T., MCGILL, K. and COLLINS, J.D., 2006. Diagnosis of Mycobacterium bovis infection in cattle by use of the gamma-interferon (Bovigam) assay. Veterinary Microbiology, vol. 112, no. 2-4, pp. 171-179. http://dx.doi.org/10.1016/j.vetmic.2005.11.029. PMid:16321478.
GREENWALD, R., LYASHCHENKO, O., ESFANDIARI, J., MILLER, M., MIKOTA, S., OLSEN, J.H., BALL, R., DUMONCEAUX, G., SCHMITT, D., MOLLER, T., PAYEUR, J.B., HARRIS, B., SOFRANKO, D., WATERS, W.R. and LYASHCHENKO, K.P., 2009. Highly accurate antibody assays for early and rapid detection of tuberculosis in African and Asian elephants. Clinical and Vaccine Immunology cvi, vol. 16, no. 5, pp. 605-612. http:// dx.doi.org/10.1128/CVI.00038-09. PMid:19261770.

HINES, N., PAYEUR, J.B. and HOFFMAN, L.J., 2006. Comparison of the recovery of Mycobacterium bovis isolates using the BACTEC MGIT 960 system, BACTEC 460 system, and Middlebrook 7H10 and 7H11 solid media. Journal of Veterinary Diagnostic Investigation, vol. 18, no. 3, pp. 243-250. http://dx.doi. org/10.1177/104063870601800302. PMid:16789711.

HUEBNER, R.E., SCHEIN, M.F. and BASS JUNIOR, J.B., 1993. The tuberculin skin test. Clinical Infectious Diseases, vol. 17, no. 6, pp. 968-975. http://dx.doi.org/10.1093/clinids/17.6.968. PMid:8110954.

INSTITUTO BRASILEIRO DE GEOGRAFIA E ESTATÍSTICAIBGE, 2009. Pesquisa Pecuária Municipal. Rio de Janeiro: IBGE.

JOLLEY, M.E., NASIR, M.S., SURUJBALLI, O.P., ROMANOWSKA, A., RENTERIA, T.B., DE LA MORA, A., LIM, A., BOLIN, S.R., MICHEL, A.L., KOSTOVIC, M. and CORRIGAN, E.C., 2007. Fluorescence polarization assay for the detection of antibodies to Mycobacterium bovis in bovine sera. Veterinary Microbiology, vol. 120, no. 1-2, pp. 113-121. http://dx.doi.org/10.1016/j. vetmic.2006.10.018. PMid:17118585

KAROLEMEAS, K., DE LA RUA-DOMENECH, R., COOPER, R., GOODCHILD, A.V., CLIFTON-HADLEY, R.S., CONLAN, A.J., MITCHELL, A.P., HEWINSON, R.G., DONNELLY, C.A., WOOD, J.L. and MCKINLEY, T.J., 2012. Estimation of the relative sensitivity of the comparative tuberculin skin test in tuberculous cattle herds subjected to depopulation. PLoS One, vol. 7, no. 8, pp. e43217. http://dx.doi.org/10.1371/journal.pone.0043217. PMid:22927952.

LEITE, C.Q., ANNO, I.S., LEITE, S.R., ROXO, E., MORLOCK, G.P. and COOKSEY, R.C., 2003. Isolation and identification of mycobacteria from livestock specimens and milk obtained in Brazil. Memorias do Instituto Oswaldo Cruz, vol. 98, no. 3, pp. 319-323. http://dx.doi.org/10.1590/S0074-02762003000300005. PMid:12886409.

MARAIS, B.J., BRITTLE, W., PAINCZYK, K., HESSELING, A.C., BEYERS, N., WASSERMAN, E., VAN SOOLINGEN, D. and WARREN, R.M., 2008. Use of light-emitting diode fluorescence microscopy to detect acid-fast bacilli in sputum. Clinical Infectious Diseases, vol. 47, no. 2, pp. 203-207. http:// dx.doi.org/10.1086/589248. PMid:18532893.

MCILROY, S.G., NEILL, S.D. and MCCRACKEN, R.M., 1986. Pulmonary lesions and Mycobacterium bovis excretion from the respiratory tract of tuberculin reacting cattle. The Veterinary Record, vol. 118, no. 26, pp. 718-721. http://dx.doi.org/10.1136/ vr.118.26.718. PMid:3526702.

MCNAIR, J., CORBETT, D.M., GIRVIN, R.M., MACKIE, D.P. and POLLOCK, J.M., 2001. Characterization of the early antibody response in bovine tuberculosis: MPB83 is an early target with diagnostic potential. Scandinavian Journal of Immunology, vol. 53, no. 4, pp. 365-371. http://dx.doi.org/10.1046/j.13653083.2001.00874.x. PMid:11285116.

MEDEIROS, L.S., MARASSI, C.D., FIGUEIREDO, E.E. and LILENBAUM, W., 2010. Potential application of new diagnostic 
methods for controlling bovine tuberculosis in Brazil. Brazilian Journal of Microbiology, vol. 41, no. 3, pp. 531-541. http:// dx.doi.org/10.1590/S1517-83822010005000002. PMid:24031527.

MEIKLE, V., SCHNEIDER, M., AZENZO, G., ZUMARRAGA, M., MAGNANO, G. and CATALDI, A., 2007. Individual animals of a cattle herd infected with the same Mycobacterium bovis genotype shows important variations in bacteriological, histopathological and immune response parameters. Zoonoses and Public Health, vol. 54, no. 2, pp. 86-93. http://dx.doi.org/10.1111/j.18632378.2007.01027.x. PMid:17348912.

MICHEL, A.L. and SIMOES, M., 2009. Comparative field evaluation of two rapid immunochromatographic tests for the diagnosis of bovine tuberculosis in African buffaloes (Syncerus caffer). Veterinary Immunology and Immunopathology, vol. 127, no. 1-2, pp. 186-189. http://dx.doi.org/10.1016/j.vetimm.2008.09.025. PMid:19007999.

MONAGHAN, M.L., DOHERTY, M.L., COLLINS, J.D., KAZDA, J.F. and QUINN, P.J., 1994. The tuberculin test. Veterinary Microbiology, vol. 40, no. 1-2, pp. 111-124. http:// dx.doi.org/10.1016/0378-1135(94)90050-7. PMid:8073619.

NEILL, S.D., CASSIDY, J., HANNA, J., MACKIE, D.P., POLLOCK, J.M., CLEMENTS, A., WALTON, E. and BRYSON, D.G., 1994. Detection of Mycobacterium bovis infection in skin test-negative cattle with an assay for bovine interferon-gamma. The Veterinary Record, vol. 135, no. 6, pp. 134-135. http://dx.doi. org/10.1136/vr.135.6.134. PMid:7975105.

NGANDOLO, B.N., MÜLLER, B., DIGUIMBAYE-DJAÏBE, C., SCHILLER, I., MARG-HAUFE, B., CAGIOLA, M., JOLLEY, M., SURUJBALLI, O., AKAKPO, A.J., OESCH, B. and ZINSSTAG, J., 2009. Comparative assessment of fluorescence polarization and tuberculin skin testing for the diagnosis of bovine tuberculosis in Chadian cattle. Preventive Veterinary Medicine, vol. 89, no. 1-2, pp. 81-89. http://dx.doi.org/10.1016/j.prevetmed.2009.02.003. PMid:19269049.

REDDINGTON, K., O'GRADY, J., DORAI-RAJ, S., NIEMANN, S., VAN SOOLINGEN, D. and BARRY, T., 2011. A novel multiplex real-time PCR for the identification of mycobacteria associated with zoonotic tuberculosis. PLoS One, vol. 6, no. 8, pp. e23481. http://dx.doi.org/10.1371/journal.pone.0023481. PMid:21858140.

RICHTER, E., WEIZENEGGER, M., FAHR, A.M. and RUSCHGERDES, S., 2004. Usefulness of the GenoType MTBC assay for differentiating species of the Mycobacterium tuberculosis complex in cultures obtained from clinical specimens. Journal of Clinical Microbiology, vol. 42, no. 9, pp. 4303-4306. http:// dx.doi.org/10.1128/JCM.42.9.4303-4306.2004. PMid:15365028.

ROBBE-AUSTERMAN, S., BRAVO, D.M. and HARRIS, B., 2013. Comparison of the MGIT 960, BACTEC 460 TB and solid media for isolation of Mycobacterium bovis in United States veterinary specimens. BMC Veterinary Research, vol. 9, no. 1, pp. 74. http://dx.doi.org/10.1186/1746-6148-9-74. PMid:23578209.

SCHILLER, I., OESCH, B., VORDERMEIER, H.M., PALMER, M.V., HARRIS, B.N., ORLOSKI, K.A., BUDDLE, B.M.,
THACKER, T.C., LYASHCHENKO, K.P. and WATERS, W.R., 2010. Bovine tuberculosis: a review of current and emerging diagnostic techniques in view of their relevance for disease control and eradication. Transboundary and Emerging Diseases, vol. 57, no. 4, pp. 205-220. PMid:20561288.

TELENTI, A., MARCHESI, F., BALZ, M., BALLY, F., BOTTGER, E.C. and BODMER, T., 1993. Rapid identification of mycobacteria to the species level by polymerase chain reaction and restriction enzyme analysis. Journal of Clinical Microbiology, vol. 31, no. 2, pp. 175-178. PMid:8381805.

UNE, Y. and MORI, T., 2007. Tuberculosis as a zoonosis from a veterinary perspective. Comparative Immunology, Microbiology and Infectious Diseases, vol. 30, no. 5-6, pp. 415-425. http://dx.doi. org/10.1016/j.cimid.2007.05.002. PMid:17706284

VORDERMEIER, H.M., WHELAN, A. and HEWINSON, G., 2008. The scientific case for the gamma interferon "BOVIGAM" assay. Government Veterinary Journal, vol. 19, pp. 38-43.

WARREN, R.M., GEY VAN PITTIUS, N.C., BARNARD, M., HESSELING, A., ENGELKE, E., DE KOCK, M., GUTIERREZ, M.C., CHEGE, G.K., VICTOR, T.C., HOAL, E.G. and VAN HELDEN, P.D., 2006. Differentiation of Mycobacterium tuberculosis complex by PCR amplification of genomic regions of difference. The International Journal of Tuberculosis and Lung Disease, vol. 10, no. 7, pp. 818-822. PMid:16850559.

WELSH, M.D., CUNNINGHAM, R.T., CORBETT, D.M., GIRVIN, R.M., MCNAIR, J., SKUCE, R.A., BRYSON, D.G. and POLLOCK, J.M., 2005. Influence of pathological progression on the balance between cellular and humoral immune responses in bovine tuberculosis. Immunology, vol. 114, no. 1, pp. 101-111. http:// dx.doi.org/10.1111/j.1365-2567.2004.02003.x. PMid:15606800.

WOOD, P.R. and JONES, S.L., 2001. BOVIGAM: an in vitro cellular diagnostic test for bovine tuberculosis. Tuberculosis (Edinburgh, Scotland), vol. 81, no. 1-2, pp. 147-155. http://dx.doi. org/10.1054/tube.2000.0272. PMid:11463236.

WORLD ORGANISATION FOR ANIMAL HEALTH - OIE, 2009. Annual animal disease status, bovine tuberculosis. Paris: OIE.

YOUNG, D.B., GIDEON, H.P. and WILKINSON, R.J., 2009. Eliminating latent tuberculosis. Trends in Microbiology, vol. 17, no. 5, pp. 183-188. http://dx.doi.org/10.1016/j.tim.2009.02.005. PMid:19375916.

YOUNG, J.S., GORMLEY, E. and WELLINGTON, E.M., 2005. Molecular detection of Mycobacterium bovis and Mycobacterium bovis BCG (Pasteur) in soil. Applied and Environmental Microbiology, vol. 71, no. 4, pp. 1946-1952. http://dx.doi. org/10.1128/AEM.71.4.1946-1952.2005. PMid:15812024.

ZUMARRAGA, M.J., MEIKLE, V., BERNARDELLI, A., ABDALA, A., TARABLA, H., ROMANO, M.I. and CATALDI, A., 2005. Use of touch-down polymerase chain reaction to enhance the sensitivity of Mycobacterium bovis detection. Journal of Veterinary Diagnostic Investigation, vol. 17, no. 3, pp. 232-238. http://dx.doi.org/10.1177/104063870501700303. PMid:15945378. 